\title{
Preliminary Report of Testing of Sites 41TV338 and 41TV386 In the Barton Creek Drainage Travis County, Texas
}

\author{
H. G. Wooldridge
}

Follow this and additional works at: https://scholarworks.sfasu.edu/ita

Part of the American Material Culture Commons, Archaeological Anthropology Commons, Environmental Studies Commons, Other American Studies Commons, Other Arts and Humanities Commons, Other History of Art, Architecture, and Archaeology Commons, and the United States History Commons

Tell us how this article helped you.

This Article is brought to you for free and open access by the Center for Regional Heritage Research at SFA ScholarWorks. It has been accepted for inclusion in Index of Texas Archaeology: Open Access Gray Literature from the Lone Star State by an authorized editor of SFA ScholarWorks. For more information, please contact cdsscholarworks@sfasu.edu. 


\section{Preliminary Report of Testing of Sites 41TV338 and 41TV386 In the Barton Creek Drainage Travis County, Texas}

\section{Licensing Statement}

This is a work produced for the Texas Department of Transportation (TxDOT) by the report producer. TxDOT and the report producer jointly own all rights, title, and interest in and to all intellectual property developed under TxDOT's contract with the report producer. The report may be cited and brief passages from this publication may be reproduced without permission provided that credit is given to both TxDOT and the report producer. Permission to reprint an entire chapter, section, figures or tables must be obtained in advance from either the Supervisor of the Archeological Studies Branch, Environmental Affairs Division, Texas Department of Transportation, 125 East 11th Street, Austin, Texas, 78701 or from the report producer. 


\section{Preliminary Report of Testing of Sites 41 TV338 and 41TV386 In the Barton Creek Drainage \\ Travis County, Texas}

BY

H.G. Wooldridge

Texas

State Department of Highways and Public Transportation Highway Design Division

September 1983 


\section{INTRODUCTION}

Testing of archaeological Sites 41 TV386 and 41TV338 was performed during the period of August 1 through September 7, 1983, by Harold G. Wooldridge and Glenn T. Goode of the State Department of Highways and Public Transportation professional cultural resources staff under auspices of Procedures for the Protection of Historic and Cultural Properties (36 CFR, Part 800), procedures prescribed and endorsed by the Federal Highway Administration.

\section{SITE $41 T V 386$}

Approximately one-third of this 250 by 600 meter site lies within the south Mopac right-of-way (Fig. 1). A surface inspection and shovel probing of the subsurface deposits were executed. Cultural material observed includes lithic reduction debris, crude bifaces, and occasionally, a thin biface fragment. No extensive clustering of materials was observed and it appears that the site is somewhat deflated. The soil consists of a thin mantle ( 1 to $35 \mathrm{~cm}$ ) of the Tarrant Series clayey soil developed from Edwards Limestone parent material of Lower Cretaceous age. As reported by McCormick (1975), the site appears to represent a lithic procurement and processing locus with little horizontal or, due to a lack of depth, vertical integrity. None of the 20 shovel probes exposed more than $35 \mathrm{~cm}$ of soil over bedrock and most revealed from 3 to 8 a of depth. Only a thin vegetative cover holds whatever pockets of soil that have developed; and, in places, bedrock is exposed.

In summary, Site 41 TV386 exhibits 1 ittle depth, lacks horizontal or vertical integrity, revealed no major cultural patterns, and offers little research potential. These observations indicate that the site does not meet the criteria for nomination to the National Register of Historic Places and merits no further work. 


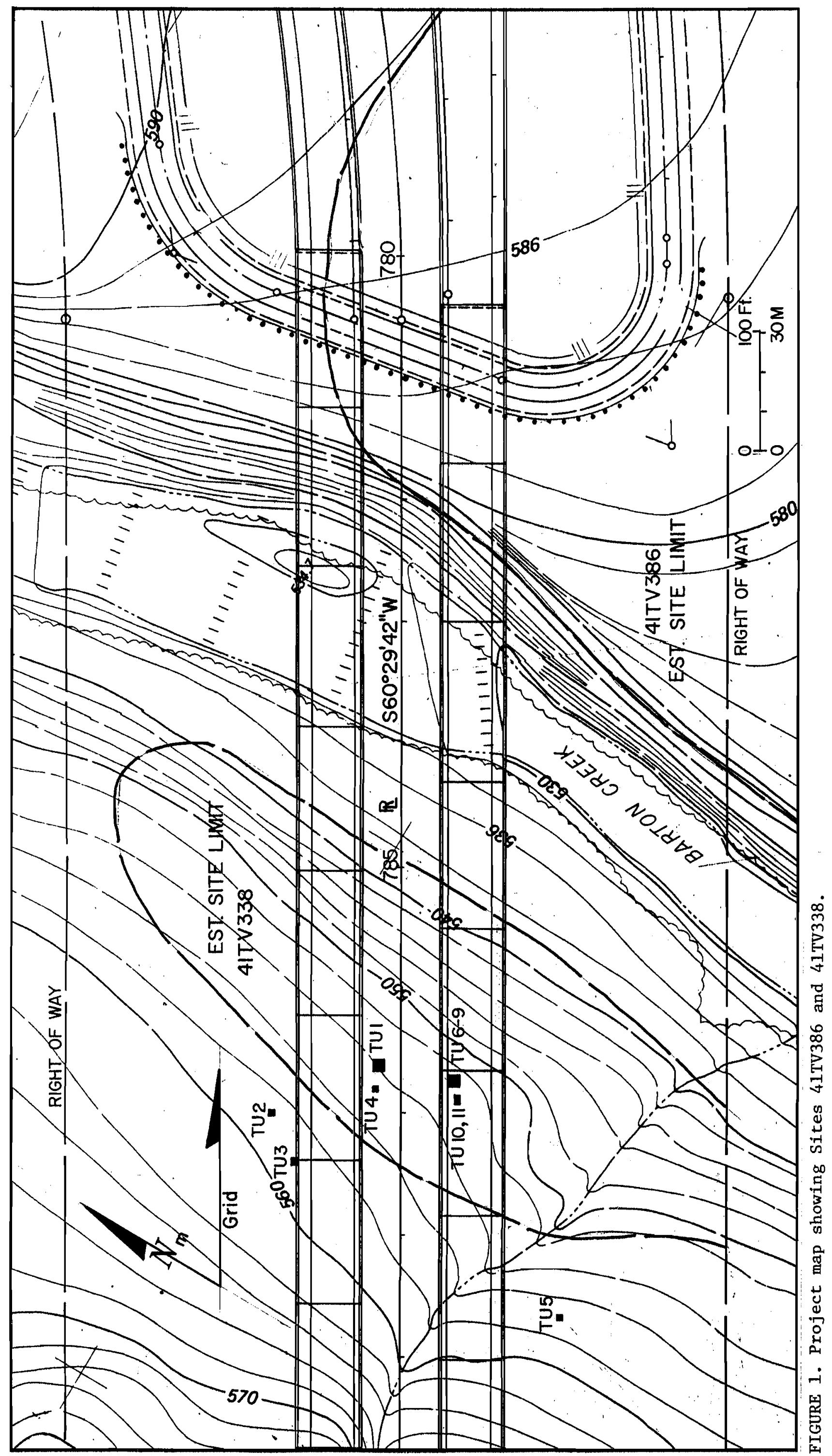


SITE $41 T V 338$

Site 41 TV338 (Fig. 1) was recorded in 1975 by Daymond D. Crawford of the State Department of Highways and Public Transportation cultural resources staff. Because of the surface exposure of a burned limestone feature containing an Angostura projectile point and the observation of a quantity of lithic debitage, subsurface investigation was recommended.

Initially, a 2 by 2 meter unit (Test Unit 1) was placed over the burned rock feature (Feature 1) and five 1 by 1 meter units (Test Units 2 through 6) were randomly placed to probe the subsurface deposits (Fig. 1). This grid was aligned with the centerline of the proposed highway and was $52^{\circ}$ east of magnetic north. All subsequent directional orientations given in this report are in reference to grid north and not magnetic north. Four of the units were west of the project centerline and two were located east of the centerline.

The units west of the centerline revealed soils of the Tarrant Series of clayey soils over Edwards Limestone of Lower Cretaceous age. The depth varied from $16 \mathrm{am}$ to $70 \mathrm{am}$ of soil over bedrock. Only a slight amount of cultural material was recovered in these units. It appears that the soil depth decreases to the west of centerline and any archaeological deposits located there would be in a deflated context.

To the south the soil depth does increase but cultural residues diminish. Only an occasional example of cultural material was recovered from Test Unit 5 (Fig. 1), and bedrock was encountered at $90 \mathrm{~cm}$ below the surface.

Burned rock Feature 1 (Fig. 2) contained primarily within Test Unit 1, was exposed, documented, and removed. This test unit, though producing a moderate quantity of material, revealed bedrock at some $40 \mathrm{~cm}$ below the present ground surface. 


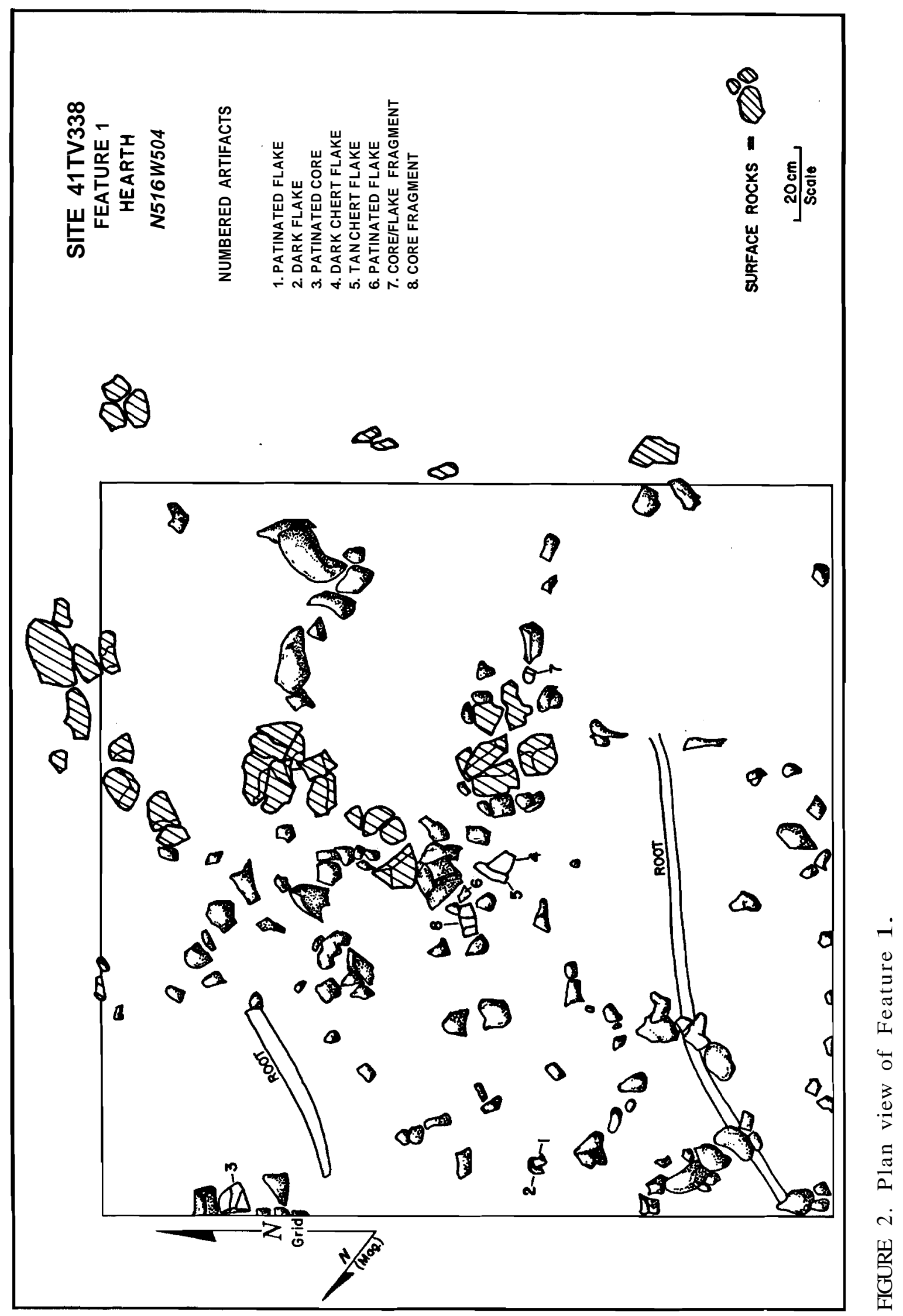


The bedrock formation tends to strike to the east and north at a moderate slope; and, following this 1 ine of evidence, a 1 by 1 meter unit (Test Unit 6) was placed 14 meters east of centerline or 20 meters east of Feature 1 to verify if, indeed, the deposits increased in depth. This unit was excavated to 1.60 meters below the surface when burned rock Feature 2 was located. The soil in this unit was a silty clay of the Altoga Series. This alluvial deposit was undoubtedly developed from overbank flooding of Barton Creek.

An additional unit (Test Unit 7) was excavated adjacent to the unit containing burned rock Feature 2 (Test Unit 6). At approximately $40 \mathrm{~cm}$ below surface in Test Unit 7, a hearth remnant (Feature 3) was encountered. After documentation, Feature 3 was removed and excavation continued until Feature 2 was again encountered. At this time, Feature 2 covered the entire floors of both Test Unit 6 and Test Unit 7. It was decided to open up two additional 1 by 1 meter units (Test Units 8 and 9) adjacent to and south of Feature 2 to further investigate this feature. These test units were excavated to the level of Feature 2 and the feature was found to extend across the entire floors and apparently beyond the walls of the four test units (Fig. 3). Therefore, two additional $\mathbf{1}$ by $\mathbf{1}$ meter units (Test Units 10 and 11) were excavated south of Units 6 through 9.

In Test Units 10 and 11, a gouge-like implement, a biface, and several burned rock clusters were encountered in association with a massive limestone boulder and two smaller boulders about 1 meter below surface. The large boulders hampered further excavation in these units; hence, the depth of Feature 2 could not be reached in Test Units 10 and 11 . It was possible to excavate around the sides of these boulders only to approximately 1.20 meters below surface. It was not determined whether the massive boulders are a bedrock formation or whether they had been transported to their present position due to natural factors (i.e., gravity, flooding, etc.) and might overlie a deeper cultural zone. It may be that the boulders were incorporated into the cultural patterning exhibited by the burned rock clusters abutting them, but as to whether they are temporally associated with Feature 2 or represent another discrete cultural zone is, without additional investigation, impossible to determine. 


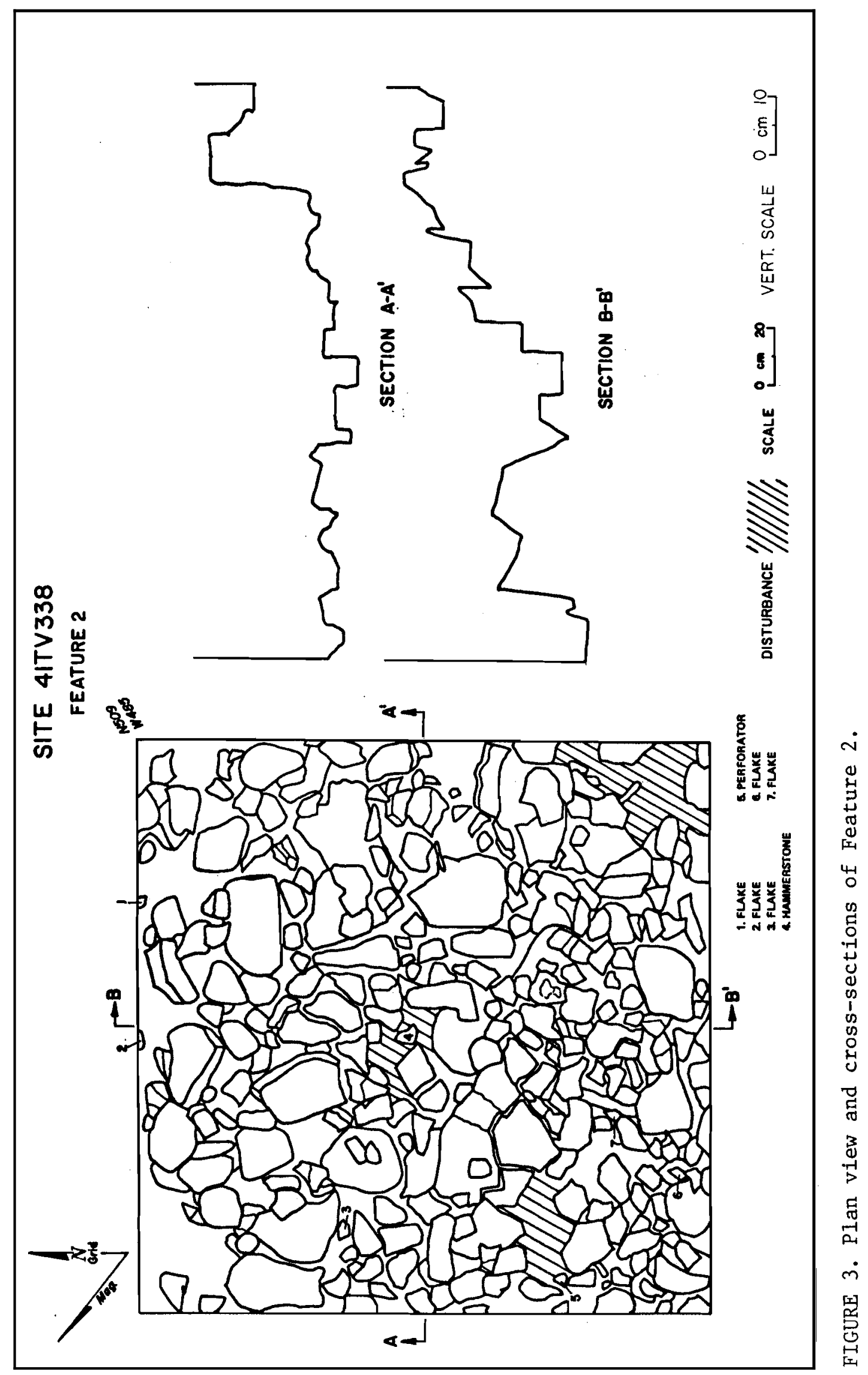


The area of occupation containing the features is obvious on the Travis County Soil Map (U.S. Department of Agriculture Soil Conservation Service 1974) as an alluvial deposit created by overbank flooding. The size of this terrace remnant is approximately 300 meters east/west by 100 meters north/south. Additional field effort would be required to assess the extent of occupation within this alluvial deposit.

In summary, Site 41 TV338 contains at least two distinct cultural zones, exhibits depositional integrity, and offers research potential. Few tools were recovered from the excavations although previous surface collection of two early styles of projectile point fragments and numerous biface fragments indicates that diagnostic as well as general purpose lithic tools do exist at site 41 TV338.

CONCLUSIONS

In view of the above data, it is felt that Site 41 TV338 meets the criteria for nomination to the National Register of Historic Places. It is felt that Site 41TV386, because of its lack of depth, depositional integrity, and cultural recovery, does not meet the criteria for nomination to the National Register of Historic Places.

REFERENCES CITED

McCormick, Olin

1975 Barton Creek Archaeological Reconnaissance, Appendix D. Environmental Analysis of Barton Creek Waste Water Interceptor. Tracor Sciences and Systems, Austin.

U.S. Department of Agriculture Soil Conservation Service

1974 Soil Survey of Travis County, Texas. Superintendent of Documents, U.S. Government Printing Office, Washington, D.C. 